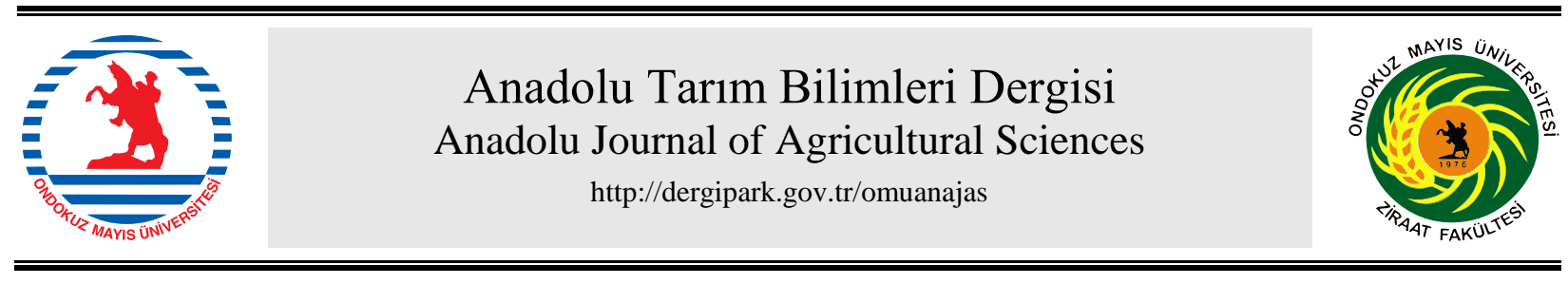

Araştırma/Research

Anadolu Tarım Bilim. Derg./Anadolu J Agr Sci, 32 (2017)

ISSN: 1308-8750 (Print) 1308-8769 (Online)

doi: 10.7161/omuanajas.289038

\title{
Tuz stresi altındaki biber (Capsicum annuum L.) bitkisinde bazı organik ve inorganik bileşiklerin antioksidatif sisteme etkileri
}

\author{
Atilla Levent Tuna*, Büşra Eroğlu \\ Muğla Sitkı Koçman Üniversitesi, Fen Fakültesi, Biyoloji Bölümü, Kötekli/Menteşe/Muğla \\ "Sorumlu yazar/corresponding author: tuna@mu.edu.tr
}

Geliş/Received 14/10/2016 Kabul/Accepted 22/11/2016

\begin{abstract}
ÖZET
Laboratuvar şartlarında saksı denemesi şeklinde yürütülmüş olan bu çalışmada, biber (Capsicum annит $\mathrm{L}$.) bitkisine $\mathrm{NaCl}(100 \mathrm{mM})$ yanı sıra, organik bileşiklerden: askorbik asit $(0.5 \mathrm{mM})$, salisilik asit $(0.1 \mathrm{mM})$, nitrik oksit (Sodium nitropruzit; $100 \mu \mathrm{M})$, prolin $(10 \mathrm{mM})$ ve inorganik bileşiklerden: silisyum $(2 \mathrm{mM})$, kalsiyum $(10 \mathrm{mM})$ ve potasyum $(10 \mathrm{mM})$ yaprak yoluyla uygulanmıştır. Tuz stresi altındaki biber bitkisinde genel vejetatif gelişme durumu ile bu organik ve inorganik bileşiklerin biber bitkisinin lipit peroksidasyon düzeyleri ve antioksidatif savunma sistemi üzerine etkinlikleri araştırılmıştır. Denemede yapılan analizler sonucunda; yapraklarda membran geçirgenliği (\% EC), prolin, klorofil ve karotenoid kapsamları, antioksidatif enzimlerden SOD, POX, CAT aktiviteleri tayini yapılmış, ayrıca bazı bitki gelişim parametreleri saptanmıştır. Aynı zamanda, yapraklarda bazı makro elementlerin ( $\mathrm{Na}, \mathrm{Ca}, \mathrm{K}$ ve $\mathrm{P}$ ) içeriği belirlenmiştir. Araştırma sonunda elde edilen verilere göre; artan tuz stresi altında biber bitkisi yapraklarında elektriksel geçirgenlik, lipid peroksidasyonu, prolin içeriği ve antioksidatif enzim aktivitelerinde artış, bazı organik ve inorganik bileşiklerin tuzlu ortama ilavesiyle bu parametrelerde düşüş gözlenmiştir. Bunun yanı sıra tuzlulukla beraber azalma göstermiş olan yaprak makro element içeriği ve ayrıca bitki uzunluğu, gövde çapı, gövde ve kök yaş ve kuru ağırlığı ortama bazı organik ve inorganik bileşiklerin eklenmesiyle olumlu olarak değişim göstermiştir. Bu bileşikler arasında lipit peroksidasyonun regülasyonunda en iyi etkiyi AsA, enzimatik antioksidatif sistemin regülasyonunda NO ve yaprak kuru ağırlığında ise $\mathrm{K}$ göstermiştir. Kontrollü şartlarda ve tuz stresi altında yetiştirilen biber bitkisinde etkinlikleri karşılaştırılmış olan organik ve inorganik bileşiklerden antioksidatif sistemi destekleyerek, bitki metabolizmasını düzenleyici ve tuz stresini hafifletmede en fazla etkiye sahip olan bileşiklerin tuzlu şartlarda kullanılabileceği ön yargısına varılmıştır.
\end{abstract}

Effects of some organic and inorganic compounds on antioxidative system in pepper (Capsicum annuum L.) plant under salt stress

\footnotetext{
ABSTRACT

In this study conducted as a pot experiment under laboratory conditions, in addition to $\mathrm{NaCl}(100 \mathrm{mM})$, some organic compounds, ascorbic acid $(0.5 \mathrm{mM})$, salicylic acid $(0.1 \mathrm{mM})$, nitric oxide (as SNP; 100 $\mu \mathrm{M})$, proline $(10 \mathrm{mM})$ and some inorganic compounds such as silicon $(2 \mathrm{mM})$, calcium $(10 \mathrm{mM})$ and potassium $(10 \mathrm{mM})$ were applied to pepper plant foliarly. Thus, general development situation in pepper plants under salt stress as well as comparative effects of these organic and inorganic compounds on lipid peroxidation and antioxidative defense system of pepper plant were investigated. At the end of analyses made during the study, membrane permeability (EC \%), proline, chlorophyll and carotenoid contents, some antioxidative enzyme activities (SOD, POX CAT) were revealed, furthermore some plant growth parameters were determined. At the same time, the content of some macro elements $(\mathrm{Na}$, $\mathrm{Ca}, \mathrm{K}$ and $\mathrm{P}$ ) in leaves were analyzed. It was observed that membrane permeability, lipid peroxidation, proline content and antioxidative enzyme activities increased in pepper leaves under ascending salinity stress, however, these parameters decreased with the addition of some organic and inorganic compounds. Additionally, the content of leaf macro element, which showed a decline with salinity, and also plant length, stem diameter, stem-root fresh and dry weights changed positively with the addition of some organic and inorganic compounds to the growth media. It was observed that among these
}

Anahtar Sözcükler: Tuzluluk Biber Dişsal uygulamalar Antioksidantlar
Keywords: Salinity Pepper Exogenous applications Antioxidants 
compounds AsA, NO and $\mathrm{K}$ were the most effective ones for suppression of lipid peroxidation, the regulation of enzymatic antioxidative system and leaf dry weight, respectively. Consequently, it was thought that the ones having the greatest effect on diminishing salinity stress and the ability of regulating plant metabolism by supporting antioxidative system among organic and inorganic compounds, of which activities were compared in pepper plant grown under salinity stress and controlled conditions, could be used under salinity.

(C) OMU ANAJAS 2017

\section{Giriş}

Optimum çevre koşullarında meydana gelen her türlü artış ya da azalış bitkide büyüme ve gelişmeyi sınırlamaktadır. $\mathrm{Bu}$ istenmeyen olumsuz koşullar stres olarak adlandırılmaktadır. Bitkide verim düşüklüğü ile sonuçlanan birçok gerilemeye sebep olan stres faktörleri abiyotik ve biyotik olmak üzere iki şekilde sınıflandırılmaktadır. Bu çalışmaya konu edilen tuzluluk stresi tüm dünyada bitki verimliliğini oldukça sınırlayan önemli abiyotik stres faktörlerinden birisidir (Yağmur, 2008). Birleşmiş Milletler Çevre Programının tahminlerine göre, dünyadaki verimli alanların yaklaşık $\%$ 50'si ile tarım arazilerinin \% 20'si tuzluluk tehdidi altındadır (Flowers ve Yeo, 1995). Yurdumuzda yaklaşık 1.5 milyon hektarlık toprak alanı tuzluluk sorunuyla karşı karşıyadır ve bunun da \% 32.5'ini sulanabilir alanlar oluşturmaktadır (Yılmaz ve ark., 2011). Gelecek 20 yıl içerisinde dünya genelinde bu oranın \% 50 oranında artış gösterebileceği ön görülmektedir (Hasanuzzaman ve ark., 2013). Yüksek tuz konsantrasyonları bitki hücresinde birçok olumsuzlukları da beraberinde getirmektedir. $\mathrm{Bu}$ olumsuzluklar üç aşamada sıralanabilir; 1-Ozmotik basıncın yükselmesiyle beraber bitki su alınımında sıkıntı yaşar ve dolayısıyla bitki beslenemez hale gelir. 2-Tuzluluğun etkisi sonucunda $\mathrm{Na}^{+}$ve $\mathrm{Cl}^{-}$iyonları yüksek konsantrasyonlara ulaştığı için bitki besin elementlerinin hücreye alınımını zorlaştırıp bitki metabolizmasını bozar. 3-İyon taşınımı sırasında ortaya çıkan dengesizlik nedeniyle hücre içindeki sıvının mineral yapısı ve $\mathrm{Ca}^{+2}$ dengesi bozulur (Ertekin, 2010). Tarımı yapılan kültür bitkilerinin tuzluluğu karşı gösterdikleri tepkiler değişmektedir. Bazı bitkiler tuzluluğa karşı hassas iken bazı bitkiler daha dayanıklı olabilmektedirler. Ortam tuzluluğu arttıkça kültür bitkilerinden elde edilen ürün miktarı bitkinin dayanıklılık düzeyine göre azalmaktadır. Örneğin bu çalışmaya konu olan biber bitkisinin eşik EC (Elektriksel geçirgenlik) değeri $1.5 \mathrm{dS} \mathrm{m}^{-1}$ olup, EC değeri $5.1 \mathrm{dS} \mathrm{m}^{-1}$ ye yükseldiğinde verimdeki göreceli azalma \% 50'ye ulaşmaktadır (Chinnusamy ve ark., 2005)

Bitkiler fotosentez, solunum ve büyüme-gelişme süreçlerinde karşılaştıkları tüm metabolik aktiviteler sonucunda hücredeki moleküler oksijenin indirgenerek çeşitli reaktif oksijen türlerinin (ROT) sentezlenmesi olgusuyla karşı karşıya gelirler (Çulha ve Çakırlar, 2012). Bu reaktif oksijen türleri olan hidrojen peroksit $\left(\mathrm{H}_{2} \mathrm{O}_{2}\right)$, süperoksit radikali $\left(\mathrm{O}_{2}{ }^{-}\right)$ve hidroksil radikali $(\mathrm{OH} \bullet)$ gibi aktif radikaller bitki hücrelerinde kloroplastlarda, mitokondriler ve peroksizomlarda meydana gelen oksidatif reaksiyon sonucu üretilmektedir. Bu oksijen türevlerinin etkisi ile lipitler, proteinler ve nükleik asitler oksidatif zarara uğramakta ve bunun sonucunda metabolizmada ciddi sorunlar meydana gelmektedir (Demiral, 2003). Herhangi bir abiyotik stres altındaki bitkiler yaşamlarını devam ettirebilmek ve stresle başa çıkabilmek için oksidatif strese cevap olarak ROT'un kontrolünü ve detoksifikasyonunu sağlayan çeşitli antioksidatif savunma mekanizmaları geliştirmektedirler. Bu koruma sistemi çalışmadığı ya da yetersiz olduğu durumlarda ise bitki hücrelerinde ölüm meydana gelmektedir (Büyük ve ark., 2012). İşte stres koşullarında canlıların genelinde olduğu gibi bitkilerde de serbest oksijen radikallerinin zararlı etkilerine karşı geliştirdikleri antioksidanları iki grupta toplamak mümkündür. Bunlar; enzimatik ve enzimatik olmayan antioksidanlardır. Bitki hücresinde temel koruyucu enzimatik antioksidanlar: süperoksit dismütaz, peroksidaz, katalaz, askorbat peroksidaz ve glutasyon redüktaz vd.'dir. Süperoksit dismutaz (SOD) enzimi, süperoksit radikalinin hidrojen peroksit ve oksijene dönüşümünü katalizleyen bir enzimdir (Alscher ve ark., 2002). Katalaz (CAT), bir elektron yakalayıcı olarak $\mathrm{H} 2 \mathrm{O} 2$ 'i kullanarak substratı okside etmekte ve H2O2'yi O2'e ve H2O'ya dönüştürmektedir. $\mathrm{Bu}$ enzim yüksek bitkilerde yoğunlukla peroksizomda bulunur (Jamei ve ark., 2009). Katalaz stres koşulları altında oluşan zararlı $\mathrm{H} 2 \mathrm{O} 2$ 'nin $\mathrm{H} 2 \mathrm{O}$ ve $\mathrm{O} 2$ 'ye direkt olarak dönüşümünü sağlayarak hücreleri, strese karşı korumada görevli en önemli enzimatik antioksidanlardan biridir. Katalaz büyük çoğunlukta peroksizomlarda, çok az miktarda da mitokondri matriksinde bulunmaktadır (Foyer ve ark., 1994).

Çalışmamıza konu olan biber bitkisi ülkemiz ve tüm dünyada yaygın olarak ve çok fazla tüketilen bir sebzedir. Vitaminler yönünden zengin olup, özellikle C vitamini bakımından oldukça değerli olan biberin 100 g'ında $160 \mathrm{mg} \mathrm{C}$ vitamini bulunmaktadır. Türkiye İstatistik Kurumu (TÜIK) 2015 verilerine göre Türkiye'de farklı tüketim amaçlarına yönelik çok çeşitli biber tiplerinin üretimi yapılmaktadır. Üretim bakımından en fazla sivri biberlerin, ardından da salçalık ve dolmalık tüketime yönelik biberlerin üretimi yapılmaktadır. 2015 yılı verilerine göre ülkemizde sivri, salçalık ve dolmalık olmak üzere toplam 2.2 milyon ton biber üretilmiştir.

$\mathrm{Bu}$ çalışmada biber bitkisinin tuzlu koşullarda direncini arttırabileceği düşünülen bir takım organik ve inorganik bileşikler dişsal olarak bitkiye verilmiştir. Bunlardan Askorbik asit'in, bitkilerde yüksek miktarda bulunup stres fizyolojisinin yanı sıra bitki büyüme ve 
gelişmesinde rol oynayan önemli bir metabolit olduğu ileri sürülmüştür (Conklin, 2001). Hücre çeperi büyümesi, hücre bölünmesi, çevresel streslere karş1 direnç, fotosentez ve etilen, gibberellin, antosiyanin, hidroksiprolin sentezlerinde önemli rol oynadığı belirlenmiştir (Smirnof ve Wheeler, 2000). Bunun yanı sıra askorbik asit (AsA), reaktif oksijen türleri içerisinde detoksifikasyon özelliği olan önemli antioksidandır (Conklin, 2001). Salisilik asit (SA) stres koşulları altında büyüme, gelişme ve savunma cevaplarında önemli rol oynayan bitki sinyal molekülüdür. SA, bitkilerde birçok metabolik ve fizyolojik cevabı oluşturan ve dolayısıyla bitki büyüme ve gelişmesini etkileyen içsel bir bitki büyüme düzenleyicisidir (Hayat ve ark., 2010). Nitrik oksit (NO) ise önemli bir sinyal molekülüdür. Bitkide patojen enfeksiyona karşı bir savunma sinyali olarak NO'nun bitkiler üzerinde düzenleyici rol oynadığı da tespit edilmiştir (Delledonne ve ark., 2001). NO'nun bitkide strese yanit olarak reaktif oksijen türleri ile birlikte bitki savunmasına katılarak, ölü hücrelerin indüklenmesi için sinyaller göndererek savunma mekanizmaları oluşturduğu ortaya konulmuştur (Neill ve ark., 2003). Bir imino asit olan prolin, $\mathrm{NaCl}$ stresi altında ozmotik regülasyonda rol oynadığ gibi, sitozolik pH ayarlanması, hücreler arası yapının ve proteinlerin bütünlüğünün korunması ve stres durumunda enzim aktivitelerinin harekete geçirilmesinde de rol oynamaktadır (Büyük ve ark., 2012). Önemli bir makro besin element olan kalsiyum (Ca), bitki büyüme ve gelişimi merkez düzenleyicisi görevini üstlenmektedir. Hücre membranlarının değiş̧im bölgelerinde kalsiyum, potasyum $(\mathrm{K})$ ve sodyum $(\mathrm{Na})$ arasında değişim ve rekabet söz konusudur. Hücre duvarında pektinler şeklinde bulunan $\mathrm{Ca}$, hücre duvarlarının ve dokularının güçlenmesinde temel görev üstlenmiştir (Kacar ve Katkat, 2006). Tuz stresi altındaki bitkilerde, potasyumun birçok enzim için kofaktör olduğu ve Ca'un dişsal uygulanmasıyla $\mathrm{NaCl}$ 'ün zararlı etkisini azaltabileceği de bildirilmiştir (Hasegawa ve ark., 2000). Potasyum bitkiler açısından alınmas1 zorunlu makro besin elementlerinden biri ve bitkide en fazla bulunan katyondur. Potasyum, bitki beslenmesinde önemli bir iyon olmakla birlikte, bitki su tüketiminde, $\quad \mathrm{CO}_{2} \quad$ özümlemesinde, enerji metabolizmasında ve yüksek molekül ağırlıklı bileşiklerin sentezlenmesindeki özel görevli sebebiyle bitkinin öncelikle tuz ve su stresi ile beraber çevresel stres türlerine karşı hayatta kalabilme yeteneğini ve toleransını arttırmaktadır. Tuzlu koşullarda ozmotik basınçtan dolayı bozulan su alım mekanizması, dışardan ilave $\mathrm{K}$ verilmesi durumunda, sodyum ile rekabet edecek K miktarını arttırmakta ve bozulmuş olan hücre içi $\mathrm{Na} / \mathrm{K}$ dengesini yeniden ayarlayarak metabolik düzenlemeyi yeniden sağlamaktadır (Kaya ve Tuna, 2005). Silisyum yüksek organizmalar için temel element olduğu görüşü öne sürülmektedir. Tuzlu topraklara uygulanan silisyum, tuzları sodyum silikat şeklinde bağlayarak bitki tarafından alınan $\mathrm{Na}$ miktarını ve bitkilerde oluşacak tuz hasarını yani tuz stresini azalmaktadır. $\mathrm{Bu}$ etki fotosentetik aktivitenin $\mathrm{K} / \mathrm{Na}$ oranının, enzim aktivitesinin ve ksilemde çözünebilir madde konsantrasyonunun artmasıyla gerçekleşir.

Tarımda hızla artan tuzluluk probleminin çözümüne küçükte olsa bir katkı sağlamak amacıyla düzenlenen bu çalışmada, tuz stresinden etkilenme potansiyeli yüksek hassas bir bitki olan biberin tuzluluğa direncini arttırabileceğini düşündüğümüz hem organik hem de inorganik bazı bileşikleri test ederek biber bitkisinin verdiği karşı yanıt araştırılmıştır.

\section{Materyal ve Yöntem}

$\mathrm{Bu}$ çalışma Muğla Sıtkı Koçman Üniversitesi Fen Fakültesi Biyoloji Bölümü Bitki Fizyolojisi Laboratuvarı'nda saksı denemesi şeklinde 3 tekerrürlü olarak 27 adet saksı ile yürütülmüştür. Uygulanan maddelerin konsantrasyonları belirlenirken geniş çaplı literatür taraması yapılmış olup, bunun sonucunda çalışma için en uygun konsantrasyonlar belirlenmiştir. Kontrol (KO) grubuna sadece sulama suyu verilmiş, tuz ( $\mathrm{NaCl} /$ Sodyum klörür olarak, $100 \mathrm{mM}$ ), AsA (Askorbik Asit $/ \mathrm{C}_{6} \mathrm{H}_{8} \mathrm{O}_{6}$ L-Ascorbic acid olarak, $0.5 \mathrm{mM}$ ), SA (Salisilik Asit/ $\mathrm{C}_{7} \mathrm{H}_{6} \mathrm{O}_{6} \mathrm{~S} \times 2 \mathrm{H}_{2} \mathrm{O}$ 5-sülfo salisilik asit dihidrat olarak, $0.2 \mathrm{mM}$ ), NO (Nitrik Oksit/ $\mathrm{Na} 2 \mathrm{Fe}(\mathrm{CN}) 5 \mathrm{NO} \times 2 \mathrm{H} 2 \mathrm{O}$ Sodyum Nitroprusside olarak, $100 \mu \mathrm{M}$ ), PRO (Prolin $/ \mathrm{C}_{5} \mathrm{H}_{9} \mathrm{NO}_{2}$ L'Proline olarak, 10 $\mathrm{mM}), \mathrm{Ca}\left(\mathrm{Kalsiyum} / \mathrm{Ca}\left(\mathrm{NO}_{3}\right) 2 \times 4 \mathrm{H}_{2} \mathrm{O}\right.$ olarak, $\left.10 \mathrm{mM}\right)$, $\mathrm{K}$ (Potasyum/KNO3 olarak, $10 \mathrm{mM})$ ve $\mathrm{Si}$ (Silisyum $/ \mathrm{Na}_{2} \mathrm{SiO}_{3}$ olarak, $2 \mathrm{mM}$ ); konsantrasyonlarında uygulanmıştır. Başlangıç deneme deseni Çizelge 1'de verilmiştir. Deneme deseninde her bir grubun tekerrürünü oluşturan saksılar tesadüf parsellerine göre rastgele yerleştirilmiş ve saksıların laboratuvar şartlarında 1şıktan optimum ve eşit oranda yararlanmaları için periyodik olarak yerleri değiştirilmiştir.

Çizelge 1. Deneme deseni

\begin{tabular}{ccccccccc}
\hline $\mathrm{NaCl}+\mathrm{Ca}_{2}$ & $\mathrm{NaCl}_{1}$ & $\mathrm{NaCl}_{2} \mathrm{AsA}_{1}$ & $\mathrm{NaCl}+\mathrm{PRO}_{2}$ & $\mathrm{NaCl}+\mathrm{K}_{1}$ & $\mathrm{NaCl}+\mathrm{PRO}_{1}$ & $\mathrm{NaCl}+\mathrm{Si}_{3}$ & $\mathrm{NaCl}+\mathrm{AsA}$ & $\mathrm{NaCl}+\mathrm{SA} A_{1}$ \\
\hline $\mathrm{NaCl}+\mathrm{SA}_{2}$ & $\mathrm{NaCl}+\mathrm{K}_{3}$ & $\mathrm{KO}_{3}$ & $\mathrm{NaCl}+\mathrm{Si}_{1}$ & $\mathrm{NaCl}+\mathrm{NO}_{2}$ & $\mathrm{KO}_{2}$ & $\mathrm{NaCl}_{2}$ & $\mathrm{NaCl}+\mathrm{K}_{2}$ & $\mathrm{NaCl}+\mathrm{Si}_{2}$ \\
\hline $\mathrm{NaCl}+\mathrm{NO}_{1}$ & $\mathrm{NaCl}+\mathrm{NO}_{3}$ & $\mathrm{NaCl}_{2} \mathrm{Ca}_{1}$ & $\mathrm{NaCl}+\mathrm{SA}_{3}$ & $\mathrm{NaCl}_{3}$ & $\mathrm{NaCl}+\mathrm{AsA}_{3}$ & $\mathrm{NaCl}+\mathrm{Ca}_{3}$ & $\mathrm{NaCl}+\mathrm{PRO}_{3}$ & $\mathrm{KO}$ \\
\hline
\end{tabular}

KO:Kontrol, NaCl: Sodyum Klorür, AsA: Askorbik Asit, SA: Salisilik Asit, NO: Nitrik Oksit, PRO: Prolin, Ca:

Kalsiyum, K: Potasyum, Si: Silisyum 
Çalışmada 2 L'lik saksıların her birine 1:1 oranlarında dere kumu ve torf doldurulmuş ve her saksıya temel gübre olarak 5'er gram katı formda 18:18:18 NPK+mikro element suda tam çözünebilir damlama sulama gübresi (gübrenin kapsamı: toplamı \% 18 olmak üzere suda çözünür formda $\% 5.5$ nitrat azotu, $\% 8.5$ amonyum azotu, \% 4 üre azotu, \% 18 potasyum oksit, \% 18 fosfor pentaoksit, \% 0.01 suda çözünür mangan ve \% 0.14 suda çözünür çinko) ilave edilmiştir. Homojenliği sağlamak için yetiştirme ortamı harcıyla gübre çok iyi bir şekilde karıştırılmıştır. Aynı gün içinde her bir saksıya 3'er tane yeşil sivri biber (Capsicum annuиm L. cv. Yalova Çarliston) fidesi dikilerek çalışma başlatılmıştır. 4 gün ara ile ortalama $250 \mathrm{~mL}$ su verilmiş, iki sulamada bir yapılan besin çözeltisi takviyesinde ise, $2000 \mathrm{ppm}$ konsantrasyonunda hazırlanan 18:18:18 NPK gübresi her saksıya 250'şer $\mathrm{mL}$ verilerek bitkilerin tüm gelişme dönemleri süresince besin maddesi gereksinimleri sağlanmıştır. Mikro besin ihtiyacını karşılamak için Fetrilon Combi besin çözeltisi (\% $\%$ 0.3'lük) olarak hazırlanmış ve yaprak yoluyla verilmiştir. Fetrilon Combi'nin kapsamı: suda tam çözünür formda \% 0.5 Bor (B), \% 1.5 Bakır $(\mathrm{Cu}), \% 4$ Demir (Fe), \% 4 Mangan, \% 0.1 Molibden (Mo) ve \% 1.5 Çinko (Zn)'dur. Gelişme süresince yapılan makro ve mikro element uygulamaları sonucunda hasat dönemine kadar bitkilerde herhangi bir noksanlık veya toksite belirtisi görülmemiştir.

Bitkilerin ortama adaptasyonlarını sağlamak amaciyla ilk uygulama, fide dikiminden 20 gün sonra başlatılmış ve kontrol grubu saksılarına sadece sulama suyu, tuz grubu saksılara sadece $\mathrm{NaCl}$ çözeltisi olmak üzere, kontrol hariç tüm grup saksılara toprak yoluyla $\mathrm{NaCl}$ çözeltisi ve diğer uygulama gruplarına yukarıda formülasyonları ile konsantrasyonları verilen organik ve inorganik çözeltiler etkinliğin ve adaptasyonun sağlanmasına yönelik olarak bir kereye mahsus olmak üzere ilk önce toprak yoluyla verilmiş ve daha sonra her 10 günde bir hasata kadar yapraktan uygulama yapılmıştır. Yapraktan uygulanan organik ve inorganik bileşikler su içerisinde çözündürüldüğünden dolayı, sadece $\mathrm{NaCl}$ (tuz) grubu saksılara ayrıca eşdeğer miktarda yapraktan sulama suyu takviyesi yapılmıştır.

Bitkiler vejetatif evreyi tamamlayip generatif evreye geçiş aşamasında 70 günün sonunda hasat edilmişlerdir. Kök ve yapraklar (sapları hariç olmak üzere) ayrı ayrı alınıp yıkandıktan sonra önce hasas terazide yaş ağırlıkları (Y.A.) belirlenmiş, daha sonra etüve alınarak $70{ }^{\circ} \mathrm{C}$ 'de 72 saat kurutulmuş ve hassas terzide tartılarak kuru ağırlıkları belirlenmiştir. \% EC yaş yaprak örneklerinde Lutts ve ark. (1996) göre, makro besin elementleri fosfor $(\mathrm{P})$, potasyum $(\mathrm{K})$, kalsiyum $(\mathrm{Ca})$ ve sodyum (Na) yaş yakma yöntemiyle ICP - OES cihazında yaprak örneklerinde kuru maddede \% olarak Kacar ve İnal (2010)'e göre, lipit peroksidasyonu Rao ve Sresty (2000)'e göre malondialdehit (MDA) ölçümü yapılarak, klorofil ve karotenoid kapsamları Strain ve Svec (1966)'e göre, prolin kapsamı Bates ve ark. (1973)'e göre, süperoksit dismütaz (SOD) aktivitesi
Beauchamp ve Fridovich'in (1971) belirlediği NBT (nitroblue tetrazoliumun) fotokimyasal azalmayı inhibe etme yeteneğinin ölçümüyle, peroksidaz (POX) aktivitesi Chance ve Maehly (1955) metoduna göre guaiacol oksidasyonu kullanılarak, katalaz (CAT) aktivitesi ise Bergmeyer (1970) metoduna göre hasattan hemen önce alınan yaş yaprak örneklerinde gerçekleştirilmiştir. Çalışmada IBM SPSS Statistics 20 programı kullanılarak tek yönlü varyans analizi ve LSD testiyle ortalamaların karşılaştırılması ve standart sapma hesaplaması yapılmıştır.

\section{Bulgular ve Tartışma}

Çalışmada elde edilen yaprak ve kökün yaş ve kuru ağırlık verileri Çizelge 2'de sunulmuştur. Çizelgede görüldüğü üzere, yaprak kuru ve yaş ağırlıkları, kök kuru ve yaş ağırlıklarının sadece sulama suyu verilen kontrol grubunda en yüksek, sadece tuz uygulaması yapılan $\mathrm{NaCl}$ grubunda en düşük olduğu ve tuza dışarıdan ilave edilen organik ve inorganik bileşiklerin etkisiyle bu parametrelerde $\mathrm{NaCl}$ grubuna göre artış olduğu gözlenmiştir. Kontrol grubuna bakıldığında kök kuru ağırlığı 1.54 iken tuz grubu ile kıyaslandığında 0.73 'e düşerek \% 86 civarında bir azalma görülmüştür. Bunun yanında tuz uygulaması tuza ilave olarak uygulanan silisyum ile kıyaslandığında kök kuru ağırlığı 0.73 'den 1.25 'e çıkarak yaklaşık \% 71 civarında bir artış göstermiştir. Yaprak kuru ağırlı̆̆ değerlendirildiğinde, kontrol grubu 5.79 iken, $\mathrm{NaCl}$ uygulaması sonucu yaprak kuru ağıllğ 2.55 'e düşmüş olup, bu azalış \% 56 civarındadır. Uygulanan tuzun etkisiyle kontrole göre yaklaşık 1.7 kat azalış gösteren yaprak kuru ağırlığı potasyum uygulamasıyla beraber sadece tuz stresine kiyasla 2.55 'ten 4.08 'e yükselerek \% 60 oranında artış göstermiş̧tir. Aynı zamanda tuz uygulaması ile nitrik oksit uygulaması ile kıyasladığında yaprak kuru ağırlığı 2.55 'ten 3.11 'e yükselmiş olup, bu artış \% 21 civarındadır. Buna göre tuz stresi altındaki biber bitkisinin kök ve yaprak kuru ağırlığında meydana gelen olumsuzlukların hafifletilmesinde bitkiye uygulanan organik ve inorganik bileşikler arasında en fazla etkiyi silisyum, en az etkiyi nitrik oksitin gösterdiği anlaşılmaktadır.

Stres altındaki birçok bitkide kök yaş ağırlık ve kuru ağırlıkları ile yaprak yaş ağırlık ve kuru ağırlıklarında önemli ölçüde azalmalar olduğu başka araştırıcılar tarafindan da rapor edilmiştir. Erkılıç (2005), tuz stresi altındaki biber bitkisinde (Capsicum annиum L.) dışarıdan uygulanan dışsal salisilik asitin yaş ve kuru ağırlık gibi bazı fizyolojik parametreler üzerine olumlu etki yaptığını bildirmiş̧ir. Kausar ve ark., (2013), tuz stresine maruz kalan buğday (Triticum aestivum) bitkisine nitrik oksit uygulamasının bitki büyümesini ve verimi olumlu yönde etkilediğini rapor etmişlerdir. Yağmur ve ark., (2006), ise tuza maruz kalan bitkinin toprak altı ve toprak üstü kuru ağırlığında meydana gelen azalmaların potasyum uygulaması ile artış gösterdiğini ve potasyumun bitki gelişimini önemli 
Çizelge 2. Tuz stresi altındaki biber bitkisine uygulanan organik ve inorganik bileşiklerin yaprak ve kökün yaş ve kuru ağırlıkları üzerine etkileri

\begin{tabular}{lcccc}
\hline Uygulamalar & Kök yaş ağırlığı(g) & $\begin{array}{c}\text { Kök kuru } \\
\text { ağırlığı }(g)\end{array}$ & Yaprak yaş ağırlığı(g) & Yaprak kuru ağılığı(g) \\
\hline Kontrol & $6.11 \pm 0.28 \mathrm{a}$ & $1.54 \pm 0.21 \mathrm{a}$ & $40.96 \pm 0.35 \mathrm{a}$ & $5.79 \pm 0.80 \mathrm{a}$ \\
$\mathrm{NaCl}$ & $3.67 \pm 0.28 \mathrm{f}$ & $0.73 \pm 0.08 \mathrm{c}$ & $22.04 \pm 0.39 \mathrm{e}$ & $2.55 \pm 0.08 \mathrm{e}$ \\
$\mathrm{NaCl}+\mathrm{AsA}$ & $4.57 \pm 0.21 \mathrm{cde}$ & $1.11 \pm 0.15 \mathrm{~b}$ & $29.77 \pm 0.24 \mathrm{c}$ & $3.53 \pm 0.11 \mathrm{~cd}$ \\
$\mathrm{NaCl}+\mathrm{SA}$ & $4.39 \pm 0.24 \mathrm{de}$ & $1.08 \pm 0.06 \mathrm{~b}$ & $29.19 \pm 0.59 \mathrm{c}$ & $3.33 \pm 0.10 \mathrm{~d}$ \\
$\mathrm{NaCl}+\mathrm{NO}$ & $4.21 \pm 0.06 \mathrm{e}$ & $1.05 \pm 0.06 \mathrm{~b}$ & $26.85 \pm 0.26 \mathrm{~d}$ & $3.11 \pm 0.12 \mathrm{~d}$ \\
$\mathrm{NaCl}+\mathrm{PRO}$ & $4.53 \pm 0.31 \mathrm{cde}$ & $1.16 \pm 0.25 \mathrm{~b}$ & $30.94 \pm 0.54 \mathrm{~b}$ & $3.86 \pm 0.11 \mathrm{bc}$ \\
$\mathrm{NaCl}+\mathrm{Ca}$ & $4.87 \pm 0.55 \mathrm{bcd}$ & $1.18 \pm 0.16 \mathrm{~b}$ & $30.96 \pm 0.25 \mathrm{~b}$ & $3.95 \pm 0.06 \mathrm{bc}$ \\
$\mathrm{NaCl}+\mathrm{K}$ & $5.01 \pm 0.08 \mathrm{bc}$ & $1.22 \pm 0.05 \mathrm{~b}$ & $31.31 \pm 0.44 \mathrm{~b}$ & $4.08 \pm 0.11 \mathrm{~b}$ \\
$\mathrm{NaCl}+\mathrm{Si}$ & $5.36 \pm 0.16 \mathrm{~b}$ & $1.25 \pm 0.09 \mathrm{~b}$ & $31.69 \pm 0.50 \mathrm{~b}$ & $3.96 \pm 0.19 \mathrm{bc}$
\end{tabular}

Çizelgedeki her bir veri üç tekrarın ortalaması \pm standart hata olarak verilmiştir. Her sütunda farklı harflerle gösterilen değerler arasındaki farklılık $\mathrm{p}<0.05$ düzeyinde istatistiksel olarak önemlidir.

derecede etkileyerek tuzun negatif etkisini azalttığını bildirmiştir.

Çalışmada araştırılan bir diğer parametre fotosentetik pigment içeriği olup, tuz stresi altındaki bitkiye uygulanan bileşiklerin klorofil a, klorofil b, toplam klorofil ve toplam karotenoid içeriklerine ait bulgular Çizelge 3.'de sunulmuştur.

Kontrol grubunda toplam klorofil içeriği 12.51 iken, $\mathrm{NaCl}$ uygulaması sonucu klorofil içeriği 5.41 'e düşmüş olup, bu azalış yaklaşık olarak \% 56 civarındadır. Uygulanan tuzun etkisiyle kontrole göre yaklaşı 2.5 kat azalış gösteren toplam klorofil içeriği $\mathrm{Na}+\mathrm{AsA}$ uygulamasiyla beraber sadece $\mathrm{NaCl}$ uygulamasiyla kıyaslandığında $5.41^{\prime}$ den 10.35 'e yükselmiş olup, artış oranı yaklaşı \% 91'dir. Bununla beraber $\mathrm{NaCl}+\mathrm{NO}$ uygulamasını sadece $\mathrm{NaCl}$ uygulamas ile kıyasladığımızda toplam klorofil içeriğinde 5.41'den 7.30'a artış görülmüş ve bu artış \% 34 civarındadır. Buna göre tuz stresi altındaki biber bitkisinde klorofil içeriğini iyileştirmede en fazla AsA, en az ise NO etkili olmuştur. Klorofil a ve b parametrelerinde de benzeri durum gözlenmiştir. Karotenoid içeriğine bakıldığında kontrol grubunda toplam karotenoid içeriği 3.05 iken $\mathrm{NaCl}$ uygulaması ile beraber 1.81' e düşmüş olup, bu düşüş \% 40 civarındadır. Uygulanan tuzun etkisiyle kontrole göre yaklaşı 1.5 kat azalış gösteren karotenoid

Çizelge 3. Tuz stresi altındaki biber bitkisine uygulanan organik ve inorganik bileşiklerin yapraklardaki klorofil a, klorofil b, toplam klorofil ve toplam karotenoid içerikleri (mg/g Y.A.) üzerine etkisi

\begin{tabular}{lcccc}
\hline Uygulamalar & Klorofil a & Klorofil b & Toplam Klorofil & Toplam Karotenoid \\
\hline Kontrol & $6.56 \pm 0.35 \mathrm{a}$ & $4.72 \pm 0.30 \mathrm{a}$ & $12.51 \pm 0.65 \mathrm{a}$ & $3.05 \pm 0.03 \mathrm{a}$ \\
$\mathrm{NaCl}$ & $3.34 \pm 0.15 \mathrm{f}$ & $2.78 \pm 0.23 \mathrm{c}$ & $5.41 \pm 0.28 \mathrm{~d}$ & $1.81 \pm 0.07 \mathrm{e}$ \\
$\mathrm{NaCl}+\mathrm{AsA}$ & $5.47 \pm 0.28 \mathrm{bc}$ & $4.23 \pm 0.07 \mathrm{~b}$ & $10.35 \pm 0,02 \mathrm{ab}$ & $2.54 \pm 0.07 \mathrm{~b}$ \\
$\mathrm{NaCl}+\mathrm{SA}$ & $5.41 \pm 0.30 \mathrm{c}$ & $4.31 \pm 0.12 \mathrm{~b}$ & $8.72 \pm 1.45 \mathrm{c}$ & $2.34 \pm 0.11 \mathrm{c}$ \\
$\mathrm{NaCl}+\mathrm{NO}$ & $4.47 \pm 0.45 \mathrm{e}$ & $3.00 \pm 0.14 \mathrm{c}$ & $7.30 \pm 0.88 \mathrm{c}$ & $2.20 \pm 0.12 \mathrm{~cd}$ \\
$\mathrm{NaCl}+\mathrm{PRO}$ & $6.38 \pm 0.30 \mathrm{f}$ & $4.26 \pm 0.26 \mathrm{~b}$ & $9.54 \pm 1.70 \mathrm{~b}$ & $2.24 \pm 0.08 \mathrm{~cd}$ \\
$\mathrm{NaCl}+\mathrm{Ca}$ & $6.05 \pm 0.62 \mathrm{f}$ & $4.39 \pm 0.28 \mathrm{ab}$ & $10.11 \pm 0.29 \mathrm{~b}$ & $2.30 \pm 0.07 \mathrm{c}$ \\
$\mathrm{NaCl}+\mathrm{K}$ & $5.20 \pm 0.16 \mathrm{~cd}$ & $4.04 \pm 0.22 \mathrm{~b}$ & $9.47 \pm 0.81 \mathrm{~b}$ & $2.21 \pm 0.10 \mathrm{~cd}$ \\
$\mathrm{NaCl}+\mathrm{Si}$ & $4.73 \pm 0.38 \mathrm{de}$ & $4.00 \pm 0.04 \mathrm{~b}$ & $9.13 \pm 0.20 \mathrm{~b}$ & $2.11 \pm 0.08 \mathrm{~d}$ \\
\hline
\end{tabular}

Çizelgedeki her bir veri üç tekrarın ortalaması \pm standart hata olarak verilmiştir. Her sütunda farklı harflerle gösterilen değerler arasındaki farklılık $\mathrm{p}<0.05$ düzeyinde istatistiksel olarak önemlidir. 
içeriği $\mathrm{NaCl}+\mathrm{AsA}$ uygulaması sonucunda 1.81 'den 2.54 'e yükselmiş, bu yükselme yaklaşık olarak \% 38 civarındadır. Aynı zamanda $\mathrm{NaCl}$ uygulaması sadece $\mathrm{NaCl}+\mathrm{Si}$ uygulaması ile kıyasladığında toplam karotenoid içeriği 1.81 'den $2.11^{\prime}$ 'e yükselerek yaklaşık $\% 16$ civarında artı̧ göstermiştir. Buna göre tuz stresi altındaki biber bitkisinde toplam karotenoid içeriğini iyileştirmede en fazla AsA, en az ise Si etkili olmuştur.

Fotosentetik dokularda tuzluluğun artış1, bitişik grana membranlarında yığılmaya, tilakoidlerin büzülmesine ve klorofillerin parçalanmasına sebep olmaktadır (Ashraf ve Harris, 2004). Tilakoidlerdeki elektron taşıma sisteminin aktivitesi yüksek tuzlulukta azalmaktadır. Yüksek tuzluluk klorofillerin moleküler yapısını bozmakta ve miktarını azaltmaktadır. Klorofil içeriğindeki azalma, klorofil sentezinin azalmasından ya da klorofil pigmentlerinin parçalanmasının artmasından kaynaklanabilmektedir. Özellikle klorofil parçalanması, klorofilaz enzim aktivitesindeki artış sonucunda ortaya çıkmaktadır (Yıldız ve ark., 2010).

Torun (2012), SA uygulamasının arpa çeşitlerinde tuz stresinin büyüme parametreleri ve fotosentetik pigment içeriklerinde oluşturduğu azalmayı iyileştirdiğini bildirmiştir. Tuna ve ark. (2008), ise silisyum uygulamasının, tuzluluğun buğday bitkisi yaprak klorofil içeriği üzerindeki negatif etkilerini kaldırdığını ifade etmişlerdir.

Araştırılan bir diğer parametre olan membran permeabilitesi veya elektriksel geçirgenlik (\% EC), özellikle tuz stresi altındaki bitkilerde hücre içi ve hücre dışı ozmotik uyumsuzluğa bağlı olarak gelişen bir iyon dengesizliği olarak tanımlanabilmektedir. EC değerinin artmasıyla birlikte hücre içi elektrolitlerinden bașta $\mathrm{Ca}$ ve K olmak üzere bazı iyonlar bitki dışına çıkmaktadır. $\mathrm{Bu}$ durum hücrede $\mathrm{Na} / \mathrm{K}$ ve $\mathrm{Na} / \mathrm{Ca}$ dengesizliklerine ve genel iyon dengesinde düzensizliklere yol açmaktadır (Ghoulam ve ark., 2002).

Şekil 1'de görüldüğü üzere tuzun etkisi ile \% EC değeri artış göstermiş ve bu etkinin azaltılmasında organik ve inorganik bileşikler önemli rol oynamıştır. Kontrol grubunda \% EC değeri 33.34 iken sadece $\mathrm{NaCl}$ grubu ile karşılaștırıldığında 66.26 'ya çıkmıș olup yaklaşık \%98 civarında artış gözlenmiştir. Tuzluluğun etkisi ile yaklaşık 2 kat artış gösteren \% EC değerinin iyileştirilmesine yönelik en fazla etkiyi gösteren kalsiyum uygulamasına bakıldığında, $\mathrm{NaCl}$ uygulamasıyla \% EC değeri 66.26 iken $\mathrm{NaCl}+\mathrm{Ca}$ uygulaması ile 43.72'ye kadar düşmüş olup, bu azalma $\% 34$ civarındadır. Aynı zamanda \% EC değeri üzerine en az etki göstermiş olan nitrik oksit $\mathrm{NaCl}$ ile kıyaslandığında \% EC değeri 66.26'dan 59.09'a gerileyerek yaklaşık \% 10 civarında azalma göstermiştir (Şekil 1). Yakıt ve Tuna (2006), tuz stresi altındaki mısır bitkisine uyguladıkları kalsiyum ve potasyumun \% EC değerini düşürdüğünü ve tuzun zararlı etkisini hafiflettiklerini rapor etmişlerdir. Çelik (2014), tuz stresi altında yetiştirilen mısır (Zea mays L.) bitkisinde artan membran geçirgenliğinin (\% $\quad$ EC) dışsal olarak uygulanan nitrik oksit ile azaldığını bildirmiştir. Tuna ve ark., (2008), tuz stresi altındaki makarnalık buğday (Triticum durum $c v$. Gediz-75) ve ekmeklik buğday (Triticum aestivum cv. İzmir-85) bitkilerine uygulanan silikonun etkilerini araştırmışlar ve tuz ilavesiyle yapraklardaki membran geçirgenliğinde artış olduğu, bu artışların $\quad \mathrm{Si}$ muamelesiyle azaldığını gözlemlenmişlerdir.

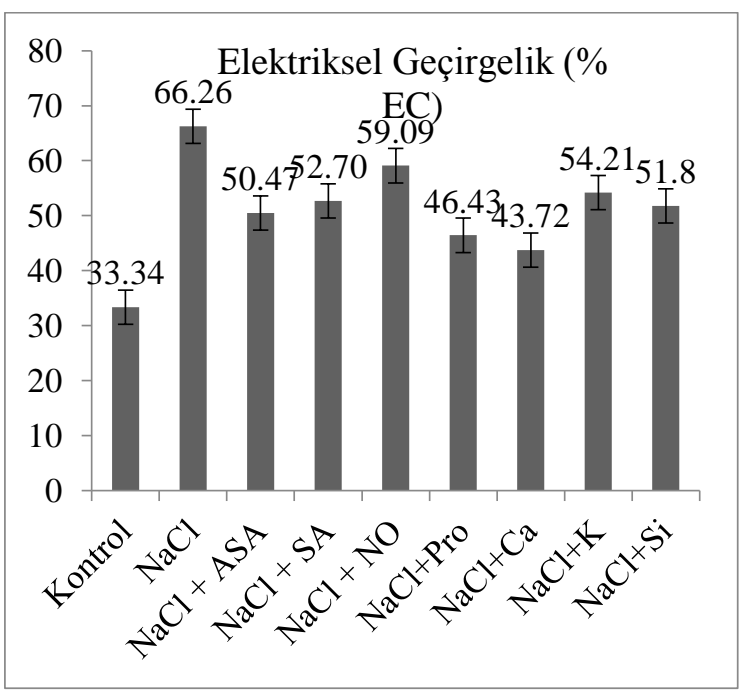

Şekil 1. Tuz stresi altındaki biber bitkisine uygulanan organik ve inorganik bileşiklerin elektriksel geçirgenlik (\% EC) üzerine etkileri

Reaktif oksijen türlerinin oluşumu stres koşullarına karşı bitkilerin meydana getirmiş olduğu genel bir tepkidir. Bu reaktif oksijen türleri bitki hücrelerinde membranların yapisında bulunan lipitleri oksitleyerek membran yapılarının bozulmasına sebep olmaktadırlar. Bunun sonucunda membran seçici geçirgenlik özelliği kaybolmakta ya da azalmaktadır. Hücre membran lipitlerinin oksitlenmesi reaksiyonlarında ara ürün olarak ortaya çıkan MDA, tuz stresi çalışmalarında stresin ne derece zarar verdiğini belirlemede önemlidir (Gossett ve ark., 1994). MDA kapsamindaki değişimlerin sunulduğu Şekil 2'de, $\mathrm{NaCl}$ grubunda kontrol grubuna göre MDA etkinliğinin yüksek seviyelere ulaşması, tuzluluğun etkisiyle hücre membranının hasara uğramış olduğunun göstergesidir. Tuzun zararı sonucunda artış gösteren MDA, bitkiye harici uygulanmış olan tüm bileşiklerin desteği ile azalma göstermiştir. Böylece hücre membranına zarar veren ROT'ların kismen de olsa temizlenmesi sağlanmıştır. Kontrol grubunda MDA kapsamı 5.12 iken sadece $\mathrm{NaCl}$ grubuna baktığımızda 20.80 'e yükselmiş olup bu artış yaklaşık \% 307 civarındadır. Uygulanan tuzun etkisiyle kontrole göre yaklaşık 4 kat artış gösteren MDA kapsamı Na+AsA uygulaması ile beraber sadece $\mathrm{NaCl}$ uygulamasıyla kıyaslandığında 20.80 'den 8.61 'e düşmüş olup, azalış oranı yaklaşık $\% 58$ 'dir. 


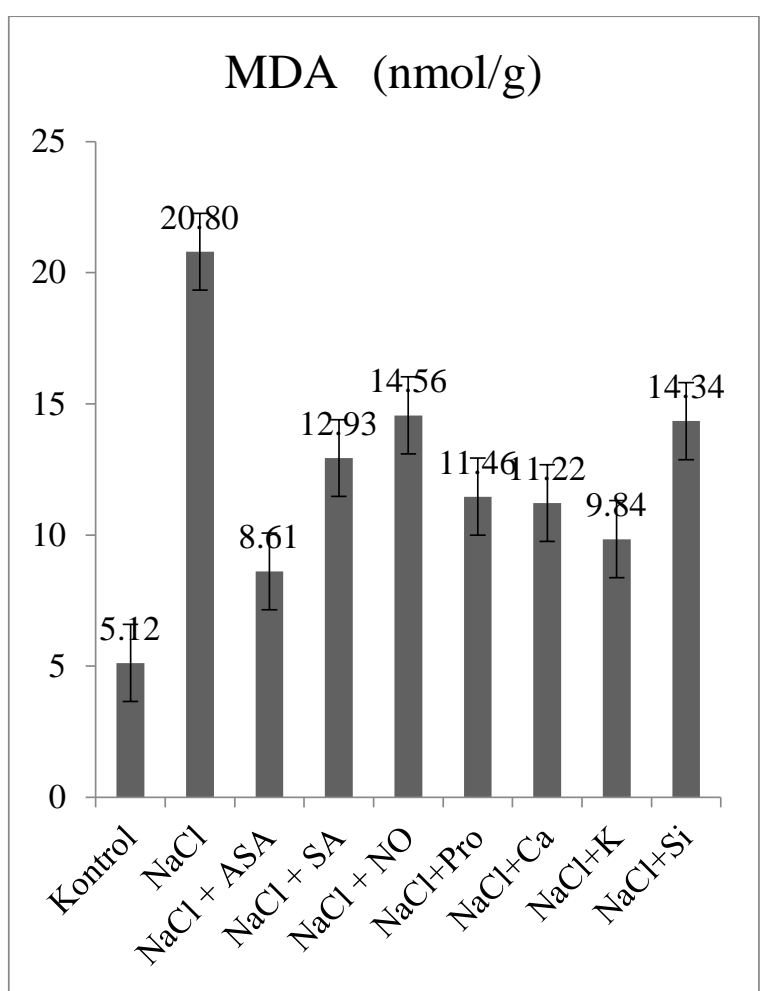

Şekil 2. Tuz stresi altındaki biber bitkisine uygulanan organik ve inorganik bileşiklerin yaprakta lipit peroksidasyonu üzerine etkileri
Aynı zamanda $\mathrm{NaCl}+\mathrm{NO}$ uygulaması sadece $\mathrm{NaCl}$ ile kıyaslandığında MDA kapsamında 20.80'den 14.56'ya düşüş saptanmış olup bu gerileme yaklaşık \% 30 'dur. Buna göre tuz stresi altındaki biber bitkisinin hücre membranında lipit peroksidasyonu sonucu açığa çıkan MDA içeriği üzerine en fazla olumlu etkiyi AsA, en az ise NO yaratmıştır (Şekil 2).

$\mathrm{Bu}$ çalışmada elde edilen bulgulara destek niteliğinde literatürde de bazı çalışmalar mevcuttur. Dolatabadian ve ark., (2008), tuz stresi altındaki kanola (Brassica napus L.) bitkisine AsA uygulaması sonucu tuzlulukla artan MDA içeriğini azalttığını, böylece AsA'in stres koşullarında bitkide hücre zarında meydana gelen hasarı onardığını bildirmişlerdir. Bak (2009), kabak bitkisinde salisilik asidin hücre membranın oksidatif hasardan etkilenme derecesi üzerine etkilerini araştırmış ve tuzun etkisiyle lipit peroksidasyonu sonucu ortaya çıkan MDA'nın salisilik asit uygulaması sonucu iyileştirdiğini ortaya koymuştur. Esim ve Atıcı (2012), stres koşulları altında mısır (Zea mays L.) yapraklarına uygulanan nitrik oksit'in (NO) lipit peroksidasyon seviyelerini önemli oranda düşürdüğünü bildirmişlerdir.

Tuzluluk koşulları altındaki biber bitkisinde, bir diğer parametre olan prolin içeriğinin de artış gösterdiği gözlenmektedir (Çizelge 4).

Çizelge 4. Tuz stresi altındaki biber bitkisine uygulanan organik ve inorganik bileşiklerin yapraklardaki prolin kapsamı ve enzim aktiviteleri üzerine etkisi

\begin{tabular}{lcccc}
\hline Uygulamalar & $\begin{array}{c}\text { Prolin } \\
(\mu \mathrm{mol} / \mathrm{g} \mathrm{Y} . \mathrm{A} .)\end{array}$ & $\begin{array}{c}\text { POX } \\
(\Delta \mathrm{A} 470 / \mathrm{min} / \mathrm{mg} \text { protein })\end{array}$ & $\begin{array}{c}\mathrm{CAT} \\
(\mu \mathrm{mol} / \mathrm{dak} / \mathrm{mg} \mathrm{Y} . \mathrm{A} .)\end{array}$ & $\begin{array}{c}\text { SOD } \\
(\text { Unit/mg protein })\end{array}$ \\
\hline $\mathrm{Kontrol}$ & $0.64 \pm 0.06 \mathrm{e}$ & $3.51 \pm 0.11 \mathrm{e}$ & $16.96 \pm 0.62 \mathrm{e}$ & $8.75 \pm 0.09 \mathrm{e}$ \\
$\mathrm{NaCl}$ & $4.56 \pm 0.71 \mathrm{a}$ & $12.70 \pm 0.45 \mathrm{a}$ & $37.55 \pm 4.62 \mathrm{a}$ & $21.68 \pm 0.95 \mathrm{a}$ \\
$\mathrm{NaCl}+\mathrm{AsA}$ & $2.81 \pm 0.37 \mathrm{~b}$ & $6.76 \pm 0.53 \mathrm{c}$ & $21.16 \pm 0.94 \mathrm{~cd}$ & $12.15 \pm 0.67 \mathrm{~d}$ \\
$\mathrm{NaCl}+\mathrm{SA}$ & $2.41 \pm 0.23 \mathrm{bcd}$ & $7.07 \pm 0.20 \mathrm{c}$ & $24.64 \pm 1.38 \mathrm{bc}$ & $16.66 \pm 0.75 \mathrm{~b}$ \\
$\mathrm{NaCl}+\mathrm{NO}$ & $2.87 \pm 0.27 \mathrm{~b}$ & $9.59 \pm 0.45 \mathrm{~b}$ & $27.40 \pm 2.16 \mathrm{~b}$ & $17.49 \pm 0.28 \mathrm{~b}$ \\
$\mathrm{NaCl}+\mathrm{PRO}$ & $2.08 \pm 0.19 \mathrm{~cd}$ & $6.79 \pm 0.16 \mathrm{c}$ & $22.65 \pm 1.01 \mathrm{~cd}$ & $14.02 \pm 0.85 \mathrm{c}$ \\
$\mathrm{NaCl}+\mathrm{Ca}$ & $1.84 \pm 0.46 \mathrm{~d}$ & $5.44 \pm 0.36 \mathrm{~d}$ & $21.32 \pm 1.98 \mathrm{~cd}$ & $13.20 \pm 0.31 \mathrm{~cd}$ \\
$\mathrm{NaCl}+\mathrm{K}$ & $2.73 \pm 0.38 \mathrm{~b}$ & $7.16 \pm 0.28 \mathrm{c}$ & $22.19 \pm 1.27 \mathrm{~cd}$ & $13.18 \pm 0.59 \mathrm{~d}$ \\
$\mathrm{NaCl}+\mathrm{Si}$ & $1.81 \pm 0.30 \mathrm{~d}$ & $6.68 \pm 0.21 \mathrm{c}$ & $20.64 \pm 0.88 \mathrm{~d}$ & $1381 \pm 0.44 \mathrm{c}$ \\
\hline
\end{tabular}

Çizelgedeki her bir veri üç tekrarın ortalaması \pm standart hata olarak verilmiştir. Her sütunda farklı harflerle gösterilen değerler arasındaki farkl1lık $p<0.05$ düzeyinde istatistiksel olarak önemlidir.

Kontrol grubunda prolin içeriği 0.64 iken $\mathrm{NaCl}$ grubunda 4.56'ya yükselerek yaklaşı 7 kat artış göstermiştir. Tuzun etkisiyle artan prolin kapsamı, dışarıdan uygulanan organik ve inorganik bileşiklerin etkisi ile azalmıştır. $\mathrm{NaCl}$ grubu sadece $\mathrm{NaCl}+\mathrm{Si}$ ile kıyaslandığında prolin içeriği 4.56 iken 1.81 'e düşerek yaklaşık \% 60 civarında bir azalma göstermiştir. $\mathrm{NaCl}$ grubu sadece $\mathrm{NaCl}+\mathrm{NO}$ ile klyaslandığında ise prolin içeriği 4.56 iken 2.87'ye azalma göstererek \% 37 civarında bir iyileştirme görülmüştür. Buna göre prolin içeriğine en fazla etkiyi silisyum, en az etkiyi ise potasyumun yaptığı anlaşılmaktadır. Prolin içeriğinde meydana gelen azalmalar, uygulanan bileşiklerin tuzun zararlı etkisini hafifletmede katkıda bulunduğunun göstergesidir.

Stres altındaki bitkiler hücrede sentezlenen ve yine hücre içerisinde sitoplazma ve organellerde bulunan organik maddeler biriktirmektedirler. Bu maddelerden bir tanesi olan prolin, membran bütünlügünün sağlanarak ozmotik dengenin korunmasında önemli rol oynamaktadır.

Stres koşullarında serbest oksijen radikallerinin oluşumundaki en önemli faktör, $\mathrm{NADP}^{+}{ }^{\prime}$ nin kısıtlı duruma gelmesi nedeniyle, ferrodoksin'in $\mathrm{NADP}^{+}$ 
yerine oksijeni indirgemesidir. Böylece membran bütünlüğüne zarar veren reaktif $\mathrm{O} 2 \bullet^{-}$radikalleri oluşmaktadır. Stres süresince kloroplastlardaki prolin biyosentez oranındaki artış, daha düşük $\mathrm{NADPH} / \mathrm{NADP}^{+}$oranı sağlayarak, hücre bütünlüğüne zarar veren reaktif $\mathrm{O}^{2} \bullet^{-}$radikallerinin oluşumunu azaltmaktadır (Miller ve ark., 2010). Özden ve ark., (2011), tuza maruz kalmış üzüm (Vitis vinifera) bitkisinde tuz varlı̆̆ında artış gösteren prolin içeriğinin prolin uygulaması ile azaldığını, stres koşullarına karşı toleranslı bitki yetiştirmede prolin uygulamalarının etkili olacağını bildirmişlerdir. Baran ve Doğan (2014), tuz stresi uygulanan arpada (Hordeum vulgare L.) strese cevap olarak prolin düzeyinin arttığını buna bağlı olarak salisilik asit uygulaması ile prolin içeriğinin azaldığını belirtmişler ve salisilik asidin tuz stresine karşı koruyucucu özellik gösterdiği sonucuna varmışlardır.

Serbest radikaller, özellikle aktif oksijen türlerinin süperoksit molekülü $\left(\mathrm{O} 2 \bullet^{-}\right)$singlet oksijen, hidrojen peroksit $\left(\mathrm{H}_{2} \mathrm{O}_{2}\right)$ ve hidroksil radikallerini $(\mathrm{OH} \bullet)$ oluşumunu içerir. Serbest radikaller, esleşmemiş elektron içeren moleküller olup oldukça reaktiftirler. Bu radikaller; plazma membranı, mitokondri, endoplazmik retikulum (ER) membranlarında da oluşabilir. Bitkiler kendilerini toksik $\mathrm{O} 2$ türevlerine karşı koruyan değişen miktarlarda antioksidanlara ve antioksidatif enzimlere sahiptirler (Ye ve ark., 2000). Bu çalışmada tüm parametrelere ilave olarak antioksidan enzimler SOD, POX ve CAT aktiviteleri de belirlenmiştir. Bu üç antioksidatif enzim de reaktif oksijen türevlerinin zararlarını yok etmek veya en aza indirmek amaciyla bitkiler tarafindan geliştirilen antioksidatif savunma mekanizmalarının önemli elemanları olup tuz stresi koşulları ile oluşan antioksidatif zararın giderilmesinde etkilidirler (Köşkeroğlu, 2006).

Araştırmada da tuz stresi sonucu biber bitkisinde bu üç enzimin de aktivitelerinde artışlar gözlenmiş, dişsal uygulanan bileşikler ile enzim aktivitelerinde azalmalar meydana gelmiştir. Elde edilen bulgular Çizelge 4'de verilmiştir.

Kontrol grubunda POX enzim aktivitesi 3.51 iken $\mathrm{NaCl}$ uygulanmasıyla 12.70 'e yükselmiş olup, bu artış yaklaşık olarak \% 270 civarındadır. Çalışmamızdaki hedefimiz tuz stresi altındaki biber bitkisinde antioksidatif sistemin dişarıdan verilen bileşikler ile desteklenip uyarılması ve serbest oksijen radikallerinin detoksifikasyonu olduğundan, bu bileşiklerin verilen tuz ile uyarılan antioksidatif sistemi ne derece etkilediği araştırılmıştır. Uygulanan $\mathrm{NaCl}$ nedeniyle kontrole göre yaklaşık 3 kat artış gösteren POX enzim aktivitesi, $\mathrm{NaCl}+\mathrm{NO}$ uygulamasiyla beraber, sadece $\mathrm{NaCl}$ uygulamasina kiyasla 12.70 'ten 9.59'a düşmüş olup düşüş oranı yaklaşık olarak \% 25 civarındadır. Aynı zamanda, $\mathrm{NaCl}+\mathrm{Ca}$ uygulamasiyla beraber bu oran 12.70 'ten 5.44 'e gerilemiş olup, bu seviyede düşüş oranı yaklaşık olarak \% 57 civarındadır (Çizelge 4). Buna göre POX enzim aktivitesini en az $\mathrm{NO}$ en çok ise $\mathrm{Ca}$ uygulamasının düşürdüğü anlaşılmaktadır.

Kausar ve ark., (2013), nitrik oksitin, tuz etkisi altındaki buğdayda antioksidan enzim aktivitesi üzerine olumlu etki yaparak, tuzun açtığı oksidatif hasara karşı koruyucu bir rol oynadığını, bitki büyümesini ve verimi olumlu yönde etkilediğini bildirmişlerdir. Başka bir çalışmada, iki çeşit (duyarlı ve toleranslı) buğday (Triticum aestivum) bitkisinin yapraklarına $250 \mathrm{mM}$ veya $500 \mathrm{mM} \mathrm{NaCl}$ ile birlikte $0.01 \mathrm{mM}$ veya $0.10 \mathrm{mM}$ salisilik asit uygulanmıştır. Tuza duyarlı olan türde POX aktivitesinde önemli düzeyde düşüş gözlemlenmiştir (Mutlu ve ark., 2009). Akat (2012), tuz stresi koşullarında örtü altı ve açık alanda yetiştirilen Deniz Lavantası (Limonium sinuatum) bitkisinde tuzluluktan dolayı bitkide meydana gelen hücresel hasarın olumsuz etkilerinin giderilmesinde kalsiyumun önemli bir rol oyandığını bildirmiştir. El-Lethy ve ark., (2013), tuzluluk stresi altında bitki metabolizmasında artış gösteren POX aktivitesinin potasyum varlığında azaldığı ve potasyumun stres kaynaklı meydana gelen oksidatif hasarı onardığını bildirmişlerdir.

Araştırmada incelenen diğer bir parametre olan CAT aktivitesine bakıldığında Çizelge 4' te görüldüğü üzere kontrol grubunda CAT enzim aktivitesi $16.96 \mathrm{iken,} \mathrm{tuz}$ uygulamasıyla beraber $37.55^{\prime}$ e yükselmiş olup, yaklaşık olarak \% 124 oranında bir artış görülmüştür. Tuz stresinin etkisini azaltmak için uyguladığımız organik ve inorganik bileşiklerin ilave edilmesiyle CAT aktivitesinde bir azalış meydana gelmiş, en fazla azalış silisyum en az azalış ise nitrik oksitte görülmüştür. $\mathrm{NaCl}+\mathrm{Si}$ uygulamasiyla beraber $\mathrm{NaCl}$ uygulamasina kıyasla CAT aktivitesi 37.55 'ten 20.64'e, yaklaşık olarak \% 45 oranında düşüş göstermiştir. $\mathrm{NaCl}+\mathrm{NO}$ uygulamasına bakıldığında $\mathrm{NaCl}$ uygulamasına kıyasla CAT aktivitesi $37.55^{\prime}$ ten $27.40^{\prime}$ a düşmüş olup bu düşüş yaklaşık olarak \% 27 oranındadır. Nejadalimoradi ve ark., (2014), tuz stresine maruz kalan Ayçiçeği (Heliantus annuus L.) bitkisine dişsal nitrik oksit (NO) uygulamalarının bitkide bazı fizyolojik parametreler ve antioksidan enzimler üzerine etkilerini araştırmışlardır. Çalı̧̧ma sonucunda kontrole kıyasla tuzlu ortama NO uygulaması ile CAT enzim aktivitesinde bir artış olduğu ve NO'nun tuzluluğu hafifletici etkisinden dolayı bir antioksidatif cevap olarak görüldügünü bildirmişlerdir. Torun (2012), arpada tuz stresinde artış gösteren CAT aktivitesinin salisilik asit uygulamasıyla azalış gösterdiğini, buna bağlı olarak salisilik asitin fizyolojik ve biyokimyasal olarak olumlu değişikliklere neden olduğunu bildirmiştir.

Çizelge 4'te kontrol grubunda SOD enzim aktivitesi 8.75 iken $\mathrm{NaCl}$ grubunda 21.68 'e yükselmiş olup, bu yükseliş \% 147 oranındadır. Uygulanan tuzlulukla beraber yaklaşık 2.5 kat artış gösteren SOD aktivitesi, $\mathrm{NaCl}+$ AsA uygulamasiyla beraber $\mathrm{NaCl}$ uygulamasina kıyasla 21.68 'ten 12.15 'e düşmüş ve düşüş oran1 yaklaşık \% 43 'tür. Aynı zamanda $\mathrm{NaCl}+\mathrm{NO}$ uygulamasına bakıldığında $\mathrm{NaCl}$ uygulamasına kıyasla SOD aktivitesi 21.68 'ten 17.49 'a gerilemiş ve düşüş oranı yaklaşık olarak \% 19 olarak görülmüştür. Sonuç olarak SOD enzim aktivitesinin tuzluluk ortamına ilavesiyle en fazla AsA, en az NO uygulamasının 
düşürdüğünü söylemek mümkündür. Dolatabadian ve ark., (2008), kanola bitkisinde tuz uygulaması ile SOD enzim aktivitesi artarken, askorbik asit uygulaması ile yapraklarda SOD enzim aktivitesinde düşüş olduğunu bildirmişlerdir. El-Lethy ve ark., (2013), buğdayda tuzluluk stresi altında bitki metabolizmasında artış gösteren SOD aktivitesinin potasyum varlığında azaldığı ve potasyumun stres kaynaklı meydana gelen oksidatif hasarı onardığı̆ı bildirmişlerdir. Özden ve ark., (2011), ise üzümde prolin uygulamasıyla POX, CAT, SOD enzim aktivitelerinde azalma olduğunu, tuz stresinin iyileştirilmesinde prolinin önemli bir rolü olduğunu bildirmişlerdir. Yaprak örneklerinin makro element kapsamlarının sunulduğu Çizelge 5’te

Çizelge 5. Tuz stresi altındaki biber bitkisine uygulanan bazı organik ve inorganik bileşiklerin yaprak \% makro element (Na, Ca, K, P) kapsamları üzerine etkisi

\begin{tabular}{lcccc}
\hline Uygulamalar & $\mathrm{Na}$ & $\mathrm{Ca}$ & $\mathrm{K}$ & $\mathrm{P}$ \\
\hline Kontrol & $0.08 \pm 0.01 \mathrm{~d}$ & $1.83 \pm 0.11 \mathrm{~cd}$ & $8.06 \pm 0.09 \mathrm{a}$ & $0.54 \pm 0.02 \mathrm{a}$ \\
$\mathrm{NaCl}$ & $2.31 \pm 0.42 \mathrm{a}$ & $1.75 \pm 0.02 \mathrm{~d}$ & $6.71 \pm 0.14 \mathrm{c}$ & $0.45 \pm 0.01 \mathrm{c}$ \\
$\mathrm{NaCl}+\mathrm{AsA}$ & $0.66 \pm 0.28 \mathrm{bc}$ & $1.90 \pm 0.14 \mathrm{~cd}$ & $7.51 \pm 0.05 \mathrm{~b}$ & $0.48 \pm 0.03 \mathrm{bc}$ \\
$\mathrm{NaCl}+\mathrm{SA}$ & $0.71 \pm 0.15 \mathrm{bc}$ & $1.84 \pm 0.20 \mathrm{~cd}$ & $7.68 \pm 0.28 \mathrm{ab}$ & $0.51 \pm 0.02 \mathrm{ab}$ \\
$\mathrm{NaCl}+\mathrm{NO}$ & $0.39 \pm 0.04 \mathrm{~cd}$ & $1.94 \pm 0.06 \mathrm{~cd}$ & $7.56 \pm 0.44 \mathrm{ab}$ & $0.51 \pm 0.03 \mathrm{ab}$ \\
$\mathrm{NaCl}+\mathrm{PRO}$ & $0.57 \pm 0.21 \mathrm{bcd}$ & $1.98 \pm 0.10 \mathrm{~cd}$ & $7.46 \pm 0.65 \mathrm{~b}$ & $0.52 \pm 0.01 \mathrm{ab}$ \\
$\mathrm{NaCl}+\mathrm{Ca}$ & $0.98 \pm 0.50 \mathrm{~b}$ & $2.58 \pm 0.12 \mathrm{a}$ & $7.68 \pm 0.57 \mathrm{ab}$ & $0.53 \pm 0.02 \mathrm{ab}$ \\
$\mathrm{NaCl}+\mathrm{K}$ & $0.71 \pm 0.31 \mathrm{bc}$ & $2.24 \pm 0.05 \mathrm{~b}$ & $7.91 \pm 0.09 \mathrm{ab}$ & $0.51 \pm 0.05 \mathrm{ab}$ \\
$\mathrm{NaCl}+\mathrm{Si}$ & $0.47 \pm 0.05 \mathrm{bcd}$ & $2.06 \pm 0.17 \mathrm{bc}$ & $6.87 \pm 0.19 \mathrm{c}$ & $0.48 \pm 0.02 \mathrm{bc}$ \\
\hline \multicolumn{2}{c}{ Cizelgedeki her bir veri üç tekrarın ortalamas1 \pm standart hata olarak verilmiştir. Her sütunda farklı harflerle gösterilen değerler } \\
arasındaki farkl11k $p<0.05$ düzeyinde istatistiksel olarak önemlidir. & &
\end{tabular}

görüldüğ̈̈ üzere $\mathrm{Na}$, kontrol grubunda $\% 0.08$ iken $\mathrm{NaCl}$ grubunda \% 2.31'e yükselerek yaklaşık 29 kat artış göstermiştir. $\mathrm{NaCl}$ grubu $\mathrm{NaCl}+\mathrm{Ca}$ ile kiyaslandığında 2.31 'den 0.98 'e düşmüş olup, bu azalış $\% 57$ civarındadır. $\mathrm{NaCl}$ grubu $\mathrm{NaCl}+\mathrm{NO}$ ile kıyaslandığında ise 2.31 'den 0.39 'a azalarak bu azalma $\% 83$ civarındadır. Buna göre tuzluluğun etkisini en fazla $\mathrm{Ca}$, en az ise NO hafifletmiștir. Kalsiyum kontrol grubunda 1.83 iken $\mathrm{NaCl}$ grubunda 1.75 'e düşmüş olup, bu azalma \% 4 civarındadır. Ca içeriği üzerine en olumlu etkiyi $\mathrm{NaCl}+\mathrm{Ca}$ grubu göstermiş olup, $\mathrm{NaCl}$ ile kıyaslandığında $\mathrm{Ca}$ içeriği yaklaşık olarak $\% 47$ civarında artış göstermiştir. En az etkiyi gösteren $\mathrm{NaCl}+\mathrm{SA}$ grubu ise $\mathrm{NACl}$ gurubu ile kıyaslandığında $\mathrm{Ca}$ içeriği \% 5 artış göstermiştir. Potasyum ise kontrol grubunda 8.06 iken $\mathrm{NaCl}$ grubunda 6.71'e düşerek \% 16 civarında azalma görülmüştür. $\mathrm{NaCl}+\mathrm{K}$ grubunu $\mathrm{NaCl}$ grubu ile kıyasladığımızda $\mathrm{K}$ içeriğinde yaklaşık olarak \% 17 civarında artıș görülmüștür. $\mathrm{NaCl}+\mathrm{Si}$ grubunu $\mathrm{NaCl}$ ile kıyasladığımızda $\mathrm{K}$ içeriğinde yaklaşık \% 2 civarında artış görülmüştür. Buna göre tuzun zararlı etkisine karşı $\mathrm{K}$ içeriğinde en olumlu etkiyi $\mathrm{K}$, en az etkiyi ise Si göstermiş̧ir. Başka bir makro element olan fosforun yapraklardaki içeriğine bakıldığında kontrol uygulamas1 ile 0.54 iken $\mathrm{NaCl}$ uygulamas1 ile 0.45 'e düşmüş olup, bu azalma yaklaşı \% 16 'dır. P içeriğginde en olumlu etki $\mathrm{NACl}+\mathrm{Ca}$ uygulamasinda olup, $\mathrm{NaCl}$ ile kıyaslandığında $\mathrm{P}$ içeriği 0.45 'ten 0.53 'e artarak, yaklaşık \% 17 oranında artma görülmüştür. Aynı zamanda $\mathrm{P}$ içeriği üzerine en az etkiyi $\mathrm{NaCl}+\mathrm{Si}$ uygulaması göstermiş ve $\mathrm{NaCl}$ uygulaması ile kıyaslandığında P içeriği 0.45 'ten 0.48 'e artmış olup, bu artış $\% 4$ civarındadır.

Tuzlu ortamlarda, bitkiler $\mathrm{K}$ ve Ca'un zararına neden olacak şekilde Na'un aşırı miktarlarını adsorbe etmektedir. Tuzlu yetiştirme ortamında yüksek $\mathrm{Na} / \mathrm{Ca}$ ve $\mathrm{Na} / \mathrm{K}$ oranları, kök membranlarının seçiciliğini bozarak Na'un köklerde ve gövdede pasif akümülasyonuna neden olabilmektedir. Bitki köklerinde Na'un yüksek oranlı akümülasyonu, kök içerisinde bulunan bazı özel yörelerin düzenleyici mekanizmalarına bağlı olabilmekte, bu da örneğin Na'un köklerden toprak üstü organlara taşınımının önlenmesine ve dolayısıyla köklerde $\mathrm{Na}$ birikimine neden olmaktadır. Na miktarındaki artış, genellikle ozmotik regülasyonu ve besin dengesini bozarak spesifik iyon toksitesine neden olmaktadır (Köşkeroğlu, 2006). Sadak ve ark. (2014), tuz stresi altındaki keten bitkisine uygulanan askorbik asidin $\mathrm{Na}$ konsantrasyonu düsürürken, $\mathrm{K}, \mathrm{Ca}$ ve $\mathrm{P}$ içeriklerinde artışa neden olduğunu gözlemlemişlerdir. Abdelhamid ve ark., (2013), tuz stresi altında fasülye bitkisine (Phaseolus vulgaris L.) yapraktan püskürtme yoluyla uyguladıkları prolinin, $\mathrm{P}$ ve K konsantrasyonlarını arttırırken $\mathrm{Na}$ iyon konsantrasyonunu azalttığını rapor etmişlerdir. Karlıda $\breve{g}$ ve ark., (2009), tuz stresinin çilek bitkisinin mineral alınımını ve büyümesini olumsuz yönde etkilemiș olduğunu ve SA uygulaması ile yaprak makro element içeriklerinde artma meydana geldiğini bildirmișlerdir. Zheng ve ark. (2009), ise dişsal NO uygulamasının buğdayda $\mathrm{Na}^{+}$konsantrasyonunu düşürürken $\mathrm{K}^{+}$ konsantrasyonunu arttırdığını bildirmişlerdir. 


\section{Sonuç ve Öneriler}

Tuzun bitkide meydana getirdiği olumsuz etkileri hafifletmek ve sağlıklı bitki gelişimi için dışsal olarak uygulanabilen bazı bileşikler tedavi edici olarak kullanılabilir. Bu çalışmadan elde edilen sonuçlara göre; tuzun özellikle hücre membran lipitleri üzerindeki hasar göstergesi sayılan lipit peroksidasyonunu önlemede AsA etkili bulunurken, yaprak kuru madde üretiminde potasyum, tuz etkisi altında enzimatik antioksidatif sistemin desteklenmesi ve regülasyonunda ise NO etkili olmuştur. Sonuç olarak; bu bileşiklerin tuz stresi altındaki bitkilerde 1slah edici rolü olduğunu düşünerek diğer kültür bitkilerinde de önerilebilir. Bunun pratiğe uygulaması zor olsa da geniş çaplı tarla denemelerine ihtiyaç duyulabilir. Bu tip kısa süreli ve dar kapsamlı çalışmalar yaptıktan sonra bu çalışmaların bilime, ekonomiye ve insanoğluna getireceği faydalar göz önüne alınmalı ve daha fazla bitki çeşidi ile daha geniş kapsamlı saks1-tarla denemeleri kurularak, elde olunan verilerin pratikte vermiş olduğu veya vereceği katkılar ayrıntılı olarak analiz edilmelidir.

\section{Kaynaklar}

Abdelhamid, M.T., Rady, M.M., Osman, A.S., Abdalla, M.A., 2013. Exogenous application of proline alleviates saltinduced oxidative stress in Phaseolus vulgaris L. Plants. J. Hortic. Sci. Biotech. 88(4): 439-446.

Akat, H., 2012. Tuz stresi koşullarında yetiştirilen Limonium sinuatum bitkisinde kalsiyum uygulamalarının verim ve gelişim kriterleri üzerine etkisi, Doktora Tezi, Ege Üniversitesi, İzmir, 184s.

Alscher R. G., Ertürk N., Heath L. S., 2002. Role of superoxide dismutases (SODs) in controlling oxidative stress in plants. J. Exp. Bot. 372: 1331-1341.

Ashraf, M., Harris, P. J. C., 2004. Potential biochemical indicators of salinity tolerance in plants. Plant Sci. 166: $3-16$.

Bak, Z.D., 2009. Tuz stresine maruz birakılan iki kabak çeşidinde (Cucurbita pepo L.) salisilik asit uygulamasıyla gelişen fizyolojik ve biyokimyasal değişimler. Yüksek Lisans Tezi. Karadeniz Teknik Üniversitesi, Trabzon, 89s.

Baran, A., Doğan M., 2014. Tuz stresi uygulanan soyada (Glycine max L.) Salisilik asidin fizyolojik etkisi. S.D.Ü. Fen Bil. Enst. Der. 18(1): 78-84.

Bates, L.S., Waldren, R.P., Teare, I.D. 1973. Rapid determination of free proline for water stres studies. Plant Soil, 39: 205-207.

Beauchamp, C., Fridovich, I., 1971. Superoxide Dismutase: Improved Assays and an Assay Applicable to Acrylamide Gels. Anal. Biochem. 44: 276-287.

Bergmeyer, N., 1970. Methoden der enzymatischen Analyse, AkademieVerlag, 1: 636-647.

Büyük, İ., Aydın, S. S., Aras, S., 2012. Bitkilerin stres koşullarında verdiği molekuler cevaplar, Türk Hijyen Deney. Biyol. Der. 69(2): 97-110.

Chance. B., Maehly, A. C., 1955. Assay of catalase and peroxidases, Methods Enzymol. 2: 764-775.

Chinnusamy, V., Jagendorf, A., Zhu, J., 2005. Understanding and improving salt tolerance in plants. Crop Sci. 45: 437-448.
Conklin, P.L., 2001. Recent advances in the role and biosynthesis of ascorbic acid in plants. Plant Cell Environ. 24: 383-394.

Çelik, A., 2014. Nitrik oksit uygulamasının tuz stresi altında yetiștirilen mısır bitkisinin mineral beslenmesi ve bazı fizyolojik özellikleri üzerine etkisi. Yüksek Lisans Tezi. Süleyman Demirel Üniversitesi Fen Bilimleri Enstitüsü, Isparta, 76s.

Çulha, Ş., Çakırlar, H., 2012. Tuzluluğun bitkiler üzerine etkileri ve tuz tolerans mekanizmaları, Afyon Kocatepe Üniversitesi Fen Bilimleri Dergisi, 11: 11-34.

Delledonne, M., Zeier, J., Marocco, A., Lamb, C., 2001. Signal interactions between Nitric oxide and reactive oxygen intermediates in the plant hypersensitive disease resistance response. Proc. Nation. Acad. Sci. 98(23): 13454-13459.

Demiral, T., 2003. Genç pirinç fidelerine dışarıdan glisinbetain uygulanmasiyla tuza $(\mathrm{NaCl})$ toleransinın arttırılmasında antioksidan enzim aktivitesinin rolünün araştırılması. Yüksek Lisans Tezi. Ege Üniversitesi Fen Bilimleri Enstitüsü, İzmir,72s.

Dolatabadian, A., Sanavy, S.A., Chashmi, N.A., 2008. The effects of foliar application of ascorbic acid (vitamin C) on antioxidant enzymes activities, lipid peroxidation and proline accumulation of canola (Brassica napus L.) under conditions of salt stress. J. Agron. Crop Sci. 194: 206-213.

El-Lethy, S.R., Abdelhamid, M.T., Reda, F., 2013. Effect of Potassium application on wheat (Triticum aestivum L.) cultivars grown under salinity stress. World Appl. Sci. J. 26(7): 840-850.

Erkılıç, E.G., 2005. Tuz stresi altındaki biber (Capsicum annuum L.) fidelerinde salisilik asitin prolin birikimi ve bazı fizyolojik özelliklere etkisi. Yüksek Lisans Tezi Ankara Üniversitesi Fen Bilimleri Enstitüsü, Ankara, $120 \mathrm{~s}$.

Ertekin F., 2010. Kabakta (Cucurbita spp.) yeşil aksam ve kök bölgesindeki iyon dağılımının tuz stresine toleransın belirlenmesinde kullanım olanakları üzerinde bir araştırma. Yüksek Lisans Tezi, Ankara Üniversitesi Fen Bilimleri Enstitüsü, Ankara, 109s.

Esim, N., Atıcı, Ö., 2012. Nitrik oksit (NO) düşük sıcaklık stresi altındaki mısırda (Zea mays L.) antioksidatif sistemi düzenler. 21. Ulusal Biyoloji Kongresi, 3-7 Eylül, İzmir.

Flowers, T.J., Yeo, A.R., 1995. Breeding for salinity resistance in crop plants where next. Australian J. Plant Physiol. 22: 875-884.

Foyer, C.H., Lelandais, M., Kunert, K.J. 1994. Photooxidative stress in plants. Phsiol. Plant. 92(4): 696-717.

Ghoulam, C., Foursy, A., Fores, K., 2002. Effects of salt stres on growth inorganic ions and proline accumulation in relation to osmotic adjustment in five sugar beet cultivars. Environ. Exp. Bot. 47: 39-50.

Gossett, D.R., Millhollon, E.P., Lucas, M.C., 1994. Antioxidant response to $\mathrm{NaCl}$ stress in salt tolerant and salt sensitive cultivars of cotton. Crop Sci. 34: 706-714.

Hasanuzzaman, M., Nahar, K., Fujita, M., 2013. Plant response to salt stress and role of exogenous protectants to mitigate saltinduced damages. P.Ahmad, M.M. Azooz, M.M.VProsod (Eds.), in: Ecophysiology and responses of plants under salt stress, pp: 25-87.

Hasegawa, P.M., Bressan, R.A., Zhu, J.K., 2000. Plant cellular and molecular responses to high salinity. Plant Mol.Biol. 51: 463-499.

Hayat, Q., Hayat, S., Irfan, M., Ahmad, A., 2010. Effect of 
exogenous salicylic acid under changing environment: A review, Environ. Exp. Bot. 68: 14-25.

Jamei, R., Heidari, R., Khara, J., Zare, S., 2009. Hypoxia induced changes in the MDA, membrane permeability, reactive oxygen species generation and antioxidative response systems in Zea mays leaves. Turk. J. Biol. 33: 45-52.

Kacar, B., Katkat, A.V., 2006. Bitki Besleme. Nobel Yayın No: 849, Fen ve Biyoloji Yayın Dizisi:29, Ankara, 589 s.

Kacar, B., İnal, A., 2010. Bitki Analizleri. Nobel Akademik Yayıncilık, 912s. Ankara.

Karlidağ, H., Yıldırım, E., Turan, M., 2009. Salicylic acid ameliorates the adverse effect of salt stress on strawberry. Sci Agric. 66(2): 180-187.

Kausar, F., Shahbaz, M., Ashraf, M., 2013. Protective role of foliar applied Nitric oxide in Triticum aestivum under saline stress. Turk. J. Bot., 37: 1155-1165.

Kaya, C., Tuna, A. L., 2005. Potasyum'un tuz stresi altındaki bitkilerde rolü ve önemi. Tarımda Potasyum Sempozyumu. 3-4 Ekim 2005, Eskişehir Osmangazi Üniversitesi.

Köşkeroğlu, S., 2006. Tuz ve su stresi altındaki mısır (Zea mays) bitkisinde prolin birikim düzeyleri ve stres parametrelerinin araştırılması. Yüksek Lisans Tezi. Muğla Üniversitesi Fen Bilimleri Enstitüsü, Muğla, 106 s.

Lutts, S., Kinet, J.M., Bouharmont, J., 1996. NaCl-induced senescence in leaves of rice cultivars differing in salinity resistance. Ann. Bot. 78: 389-398.

Miller, G., Suzuki, N., Ciftci-Yilmaz, S., Mittler, R. 2010. Reactive oxygen species homeostasis and signalling during drought and salinity stresses. Plant Cell Environ. 33: 453-467.

Mutlu, S., Atici, O., Nalbantoglu, B., 2009. Effects of Salicylic acid and salinity on apoplastic antioxidant enzymes in two wheat cultivars differing in salt tolerance. Biol. Plantarum, 53: 334-338

Neill, S.J., Desikan, R., Hancock, J.T., 2003. Nitric oxide signalling in plants. New Phytolol., 159:11-35.

Nejadalımoradi, H., Nasibi, F., Kalantari, K.M., Zangahe, R., 2014. Effect of seed priming with L-arginine and Sodium nitroprusside on some physiological parameters and antioxidant enzymes of sunflower plants exposed to salt stress. Agric. Commun., 2(1): 23-30.

Özden, M., Dikilitaş, M., Gürsöz, S., Ak, B.E., 2011. 110r anacı üzerine aşılı şiraz üzüm (Vitis Vinifera L.) çeşidinin $\mathrm{NaCl}$ ve prolin uygulamalarına karşı fizyolojik ve biyokimyasal tepkileri. Harran. Ü.Z.F. Der. 15(1): 19.
Rao, K.V.M., Sresty, T.V.S., 2000. Antioxidative parameters in the seedlings of pigeonpea (Cajanus cajan L.) in response to Zn and Ni stresses. Plant Sci. 157: 113-128.

Sadak, M.S., Dawood, M.G., 2014. Role of Ascorbic acid and Tocopherol in alleviating salinity stress on Flax plant (Linum usitatissimum L.). J. Stress Physiol. Biochem. 10(1): 93-111.

Smirnof, N., Wheeler, G. L., 2000. Ascorbic acid in plants: biosynthesis and function. Crit. Rev. Biochem. Mol. Biol. 35(4): 291-314.

Strain, H.H., Svec, W.A., 1966. Exraction, separation, estimation and isolation of chlorophylls. 21-66, Bernon, V.P., Seely, G.R. (eds.), In the chlorophylls Academic Pres, New York.

Torun, H., 2012. Tuz stresine maruz birakılan arpa (Hordeum vulgare L.) çeşitlerinde Salisilik asit muamelesinin içsel fitohormonlar düzeyinde fizyolojik ve biyokimyasal etkilerinin araştırılması. Doktora Tezi. Karadeniz Teknik Üniversitesi Fen Bilimleri Enstitüsü, Trabzon, $104 \mathrm{~s}$

Tuna, A.L., Kaya, C., Higss, D., Morillo-Amador, B., Aydemir, S., Girgin, A.R., 2008. Silicon improves salinity tolerance in wheat plants. Environ. Exp. Bot. 62(1): 10-16.

Yağmur, M., Kaydan, D., Okut, N., 2006. Potasyum uygulamasinın tuz stresindeki arpanın fotosentetik pigment içeriği, ozmotik potansiyel, $\mathrm{K}+/ \mathrm{Na}+$ oranı ile bitki büyümesindeki etkileri. Tarım Bil. Der. 12(2): 188-194.

Yağmur, Y., 2008. Farklı asma (Vitis vinifera L.) çeşitlerinin kuraklık stresine karşı bazı fizyolojik ve biyokimyasal tolerans parametrelerinin araștırılması. Yüksek Lisans Tezi, Ege Üniversitesi Fen Bilimleri Enstitüsü, İzmir, 108s.

Yakıt, S., Tuna, A.L., 2006. Tuz stresi altındaki misır bitkisinde (Zea mays L. ) stres parametreleri üzerine Ca, Mg ve K'nın etkileri. Akdeniz Üniv. Der. 19(1): 59-67.

Ye, Z., Rodriguez, R., Tran, A., Hoang, H., Los Santos, D.D., Brown, S., 2000. The developmental transition to flowering repsesses ascorbate peroxidase activity and induced enzymatic lipid peroxidation in leaf tissue in Arobidopsis thaliana. Plant Sci. 158: 115-127.

Yıldız, M., Terzi, H., Cenkci, S., Arıkan, E. S., Uruşak, B., 2010. Bitkilerde tuzluluğa toleransın fizyolojik ve biyokimyasal markörleri. Anadolu Üniv. Bilim Tekn. Derg. 1(1): 1-33.

Y1lmaz E., Tuna A. L., Bürün B., 2011. Bitkilerin tuz stresi etkilerine karşı geliştirdikleri tolerans stratejileri. C.B.Ü. Fen Bilimleri Dergisi, 7(1): 47-66.

Zheng, C., Jiang, D., Liu, F., Dai, T., Jing, Q., Cao, W., 2009. Effects of salt and waterlogging stresses and their combination on leaf photosynthesis, chloroplast ATP synthesis, and antioxidant capacity in wheat. Plant Sci. 176: 575-582. 